Алија Х. Хоџић ${ }^{1}$

Институт за друштвена истраживања у Загребу

Загреб (Хрватска)
УДК 316.334.55(049.32)

Ocвp $\bar{u}$

Прихваћен 3.11.2017. doi:10.5937/socpreg51-15312

\title{
О РУРАЛНОСТИ
}

Кратки осврт на зборник „Социологија руралног развоја” (Сретен Вујовић, Београд, Завод за уџбенике, 2016, 708 стр.)

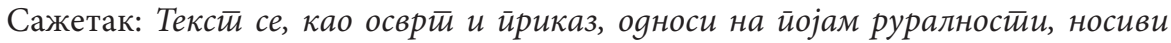
йојам у зборнику раяова „Социолоіија руралноі развоја”. Указује се на сложености и

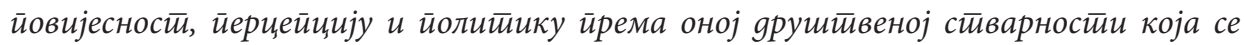

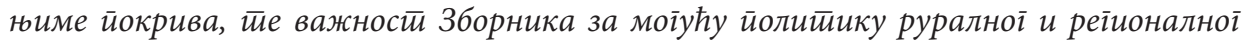
развоја.

Кључне ријечи: руралносй, сельашӣво, бинарне йоgјеле, комуникације, рекомӣозиција.

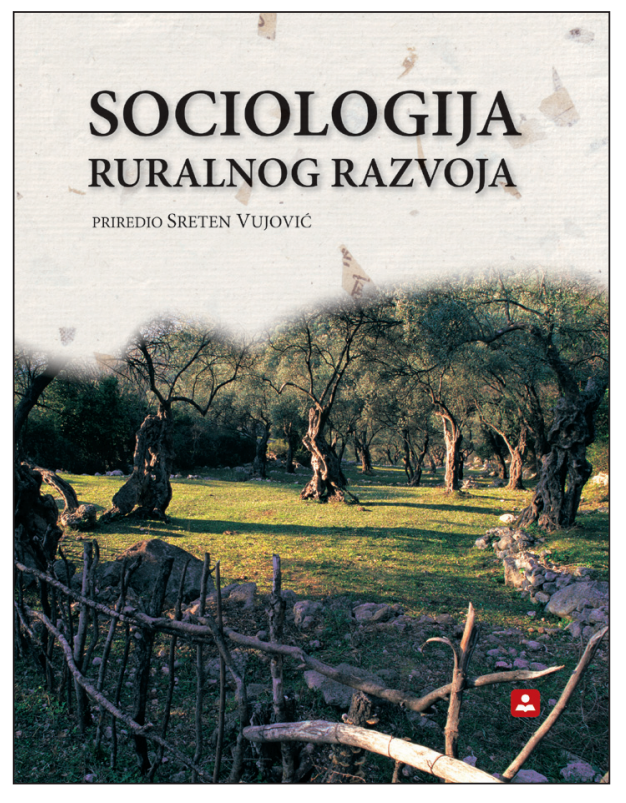

1 alija@idi.hr
Прије 5-6 година, први пут је, према критеријима појединих држава, сеоско становништво на кугли земаљској пало испод 50 \%. Дистрибуција тог становништва по појединим земљама је изразито различита. У неким земљама тзв. трећег свијета, у Азији и Африци, и данас преко 2/3 становништва чини сеоско становништво. У Европи, опет, са знатним разликама, у широко дефинисаним руралним подручјима живи око 40 \% њеног становништва. А наспрам тог становништва, које је тенденцијски у сталном опадању, јесте становништво градова - све већих и већих градова. И онда када је сеоско становништво сасвим доминирало на читавом европском простору, ни тада оно није доминирало у структури моћи унутар ширих поли- 
тичких заједница којима је припадало. Моћ је била настањена изван њега. Заправо, сељаштво и село се и дефинишу кроз њихов однос с тим надмоћним Другим.

Анри Мандрас, познати француски социолог (заступљен у овом зборнику), врло је опрезан када истражује сељаштво и сељачка друштва (Mendras, 1986). Он није склон оном путу који га води или који би га одвео трагом неког опшег, свевременског и супстанцијалног одређења сељаштва јер тог „битног”, чија се „вјечна душа” одржала пробијајући се „кроз мноштво хисторијских промјена”, сматра он, заправо и нема. Своје ће истраживачке напоре усмјерити ка јасно омеђеном и времену и простору: сељацима западне Европе између 1000. и 2000. године. На систематизацији знања о њима градит ће модел који би, можда, помогао и у истраживању других типова сељачких друштава. Други за сељаке у овом европском случају су, на почетку, властела, а затим је то град: „док нема”, каже Мендрас, „властелина или града нема ни сељака”. Када урбанизирано и индустријализирано друштво поништи релативну аутономију сељачких колективитета, сељак ће бити претворен у пољопривредника, сељана који ће као и грађанин постати потрошач - престат ће, као што то чини и грађанин, пећи и властити хљеб. Из тог одређења Мендрас ће се запитати о крају сељаштва. Као и многе бинарне опозиције и опозиција град-село, урбаност-руралност хисторијски је одређена. (Па, чак и оне бинарне опозиције које су природне и чине нам се трајним, непромјенљивим: нпр. мушко-женско или дан и ноћ; колико су се промијениле врсте наших дневних и ноћних активности од, на пример, оног времена кад се у старом Риму знатно строже кажњавала иста крађа направљена по ноћи од оне направљене дању?) Ову Мендрасову бинарну опозицију, при одређењу сељаштва, искористит ће француски хисторичар (такођер заступљен у овом зборнику) Емануел Ле Рој Ладир (Еmmanuel Le Roy Ladurie) да би одредио оно што је у фокусу његовог истраживачког интереса - руралну цивилизацију. Она се, како сам каже, дефинише понајприје кроз супротности. Ко каже село, самим тим каже град: ко каже сељаци, каже грађани. Рурална цивилизација јесте једнолико ткиво које окупља известан број ћелијских група, села, парохија или комуна: те групе, зависно од случаја, обухватају, или пак њима доминирају, неке моћи или (и) економске и друштвене снаге које су спољашње или надређене споменутим ћелијама. Међу таквим моћима и снагама, које коегзистирају или пак следе једна за другом, можемо споменути феудализам, градове, државе, трговину и индустрију, капитализам, страначку или полицијску бирократију, итд. Свако је село, као што примећује Мендрас, обгрљено околним друштвом (другим селима), те наткриљујућим или доминирајућим друштвом (грађани, феудалци, капиталисти, бирократија, свештенство или полиција) (Le Roy Ladurie, u Vujović, 2016, стр. 128).

Сви су они, осим једним дијелом феудалаца, смјештени у град. Када их има на селу, трајно или повремено, представници су моћи која је смјештена у град. Подјела становништва на сеоско и градско, њихова бинарна опозиција, подјела је дугог трајања. Једна је и од дуготрајних друштвених супротности. Не зачуђује да има и своју рефлексију у социологији, и у изградњи концепата и у опису истраживаних феномена укључујући и оне оцјене које је о сељаштву још од средњовјековља градио градски човјек - с понеким изузетком везаним уз културни и политички руризам. Тако, код оних који су власници владајућег дискурса, дакле града и његове 
интелигенције „реч сељак”, у Declinatio rustica, из XIII стољећа, истиче Жак Ле Гоф (Jacques Le Goff, 1982), а у уводној студији овог зборника наводи његов приређивач, „има шест значења: нитков, геак, лупеж, неверник, разбојник, пљачкаш; а у множини - бедници, просјаци, лажови, силеџије, ђубрета, неверници”. Пристојност, уљудност, углађеност, умјереност, рационалност итд. и данас су у владајућем дискурсу смјештени у град, а не на село. У нашој свијести понекад се задржавају старе представе иако оне у самом животу не налазе снажно упориште. Донекле, али само донекле, тако је и са бинарном опозицијом град-село, урбаност-руралност која се користи у социологији. Потребна је (још увијек) кад служи као истраживачко оруђе, као елементарно средство за сређивање комплексне, вишезначне и промјенљиве стварности; штетна је пак када запречава или отежава препознавање стварне разноликости и промјенљивости истраживаних феномена.

Проблем руралности (а тиме и урбаности) централни је проблем овог зборника, па и онда кад се и не спомиње. Он се јавља у свим текстовима, непосредно или посредно, како у уводној студији, тако и у осталим у зборнику уврштеним текстовима - различитим и по начину третирања и по времену настанка: од оних којима се испитује предмет социологије руралног развоја и пита што се у стварности покрива и може покрити тим или њему сличним појмом, преко текстова који залазе у релативно далеку или блиску прошлост, текстова који анализирају промјене настале у процесу модернизације друштва и оних у који анализирају садашње стање села и сељаштва (његову репродукцију и културу), па до оних који се баве руралним развојем у контексту постсоцијалистичке трансформације села и сеоског становништва у савременој Србији. Појмом руралности, а увијек с експлицитном или имплицитном компарацијом с појмом урбаности (јер град је носилац промјене и модерности, у њему се „кухају” промјене које ће понекад тек површно запљуснути, а понекад сасвим заокупити живот и машту сеоског становништва) најчешће се односи на мања насеља с ниском густоћом насељености и изграђености, насеља с мање развијенијом подјелом рада и она у којима су ријетко смјештене неке од централних функција (за друга слична насеља, а најчешће их и нема), насеља у којима је пољопривреда значајна дјелатност (за неке, основна, за неке друге додатна, а за неке пак треће као рекреативна, дјелатност). То су насеља која су смјештена у пејзаж, шири простор испуњен пољима, воћњацима, башчама, шумама, пашњацима, понекад и водама, простор који се, са својим ресурсима, користи и валоризира не само кроз пољопривреду већ и, зависно од прилика, кроз шумарство, рударство, електропривреду, водопривреду, туризам, здравство, рекреацију и сл., а с којим та насеља, повезана са себи сличним насељима и неким мањим градом, чине цјелину руралног простора. Отуда се и развој тих подручја не може посматрати само, па ни претежно, кроз пољопривредну дјелатност, већ као интегралан развој у ком еколошки поглед на развој заузима важно, а можда и најзначајније мјесто.

За овладавање и сређивање настале друштвене комплексности у процесу модернизације села, често у вези с циљевима појединих истраживачких настојања, нуде се различити обрасци. Овдје ћу да споменем један од њих, који може послужити за више дисциплина - и за социологију, и за антропологију и за социјалну географију. На примјеру истраживања села западне Европе, а понајвише Француске, 
понудио нам га је Бенар Кајзер (Bernard Kayser, 1990). Унутар његовог препознавања про-цеса ренесансе села он процес трансформације под утицајем модернизације дијели на два јасно препознатљива периода. Након етапе у којој се сеоска заједница налазила у стању коегзистенције различитих занимања (пољопривреда, сеоске занатлије, трговци), етапе композиције, настала је у изразито индустријској фази модернизације, етапа декомпонирања села (етапа декомпозиције) у којој се село кроз аграризацију настојало учинити монофункционалним, да би у савременим условима (управо захваљујући модерном развоју - с новим облицима организације рада, развојем цестовне и друге сеоске инфраструктуре, новим средствима комуникације и сл.) село постало мјесто и рада и становања за људе различитих занимања, па и оних са повећаним аспирацијама. Ову нову ситуацију, тек у настанку, Кајзег назива рекомпозицијом. Отуда онда и ренесанса сеоских подручја.

Ренесансу руралности, ваља пак критички разматрати: од Португала до Родопа у Бугарској планинска подручја, уколико немају туристичко-рекреацијску или неку другу производну функцију, захваћена су депопулацијом, старењем становништва и у складу с тим, смањењем привредних активности. У осталим дијеловима европског простора ренесанса се односи понајвише на руралне просторе који се налазе у близини или релативној близини градских насеља (и при томе, тенденцијски, губе своја обиљежја и у погледу ресурса, просторне и социјалне густоће, а свакако и пејсажно); такођер, претежно и у оним насељима која су смјештена на релативно значајнијим путним комуникацијама. Открива се, заправо, да је савремени систем комуникација кључ за разумијевање ове ренесансе. Из перспективе временско-просторног сажимања Дејвида Харвија (David Harvey, 1989), као посљедице савремених транспортних и телекомуникацијских средстава и технологија, гдје просторна блискост није претпоставка блискост међу људима, нова конфигурација простора поприма и нове односе села и града, па и нове дефиниције и класификације. За сада, према резултатима истраживања, досадашња подјела још увијек даје задовољавајуће резултате. Не показује се стриктна одвојеност руралног и урбаног, такођер, долази до њиховог прожимања, али још увијек дистрибуција структурних (економских, социјалних, политичких и културних) обиљежја показује значајне разлике међу њима. Овдје нам, да споменем Карла Маркса (Karl Marx), анатомија човјека, помаже приликом разумијевања анатомије мајмуна, тј. концепт урбаност-руралност (гдје град генерира и шири нове вриједности) с појмом рекомпозије руралности (или неким њему сличним појмом) као апаратима за разумијевање садашњости, истовремено служе и за боље разумијевање оних путова и структура којима је ходило село и сељаштво и у којима је живјело и репродуцирало се. Подјела становништва на урбано и рурално није само одржива на свјетском нивоу, већ и у развијеној западној Европи у којој се у руралним подручјима биљеже и нове праксе њиховог становништва.

Текстови објављени у овом зборнику из различитих полазишта у својој укупности захватају читаву лепезу проблема којима се бавила социологија села и којима се данас бави социологија руралног развоја: од уводне студије до текстова у другом дијелу зборника сврстаних у шест поглавља - од базичних текстова из области ове социолошке дисциплине до текстова који у савременој Србији препознају проблеме руралног и регионалног развоја. 
Данас се рурални простори изнова проблематизирају; није реч само о експлоатацији њихових ресурса већ и о њиховој заштити, која постаје нови важан развојни ресурс. Производња је простора данас рефлектирана модерност која досадашњи процес модернизације захваћа из нараслих проблема савременог друштва. То значи да рурални простор ваља изнова перципирати и валоризирати. Организација перцепције је пак посредована увидима у ранији развој руралности, његове трансформације, у већ произведене, али и могуће посљедице - скупом систематизираног знањем, увидима о руралности из различитих полазишта. Да би, дакле, могли изнова производити рурални простор, организовати нову перцепцију и нову валоризацију, ваља поћи од знања и искустава стечних до сада. Овај зборник својом опширном уводном студијом и, такође, врло опширним избором текстова, нуди ваљано полазиште за то.

Сретен Вујовић, аутор уводне студије (Vujović, 2016, стр. 17-99) и приређивач овог зборника, каже да зборник „треба првенствено да послужи као уџбеничка литература студентима на разним нивоима студија и разним факултетима” али, такође, може послужити и онима који се баве друштвеним и хуманистичким наукама и широј читалачкој публици. Могли би се навести бар још неки могући корисници: уколико би се уклонио нехај који влада у структурама власти Србије и стручних служби које их опслужују (важних актера у производњи простора), онда би им овај зборник могао послужити за формирање савремене перцепције и валоризације руралних простора, њиховом планирању и развоју - од општинског до државног нивоа. 
Alija H. Hodžić, On rurality...

Alija H. Hodžić ${ }^{1}$

Institute for social research in Zagreb

Zagreb (Croatia)

\title{
ON RURALITY
}

\author{
A brief review of the "Rural Development Sociology" collection \\ (Sreten Vujović, Beograd, Zavod za udžbenike, 2016, 708 pp)
}

(Translation In Extenso)

Abstract: This text, both a review and an overview, refers to the notion of rurality, the supporting concept of the collection of papers "Rural Development Sociology”. It points to the complexity and historicity, perception and politics of the social reality that the notion of rurality covers, and to the importance of the Collection for possible rural and regional development policy.

Keywords: rurality, peasantry, binary divisions, communications, recomposition.

Fall of the rural population under 50\% was first time registeredsix or seven years ago and according to the criteria of individual countries, where this percentage variated. In some, so called „third world“ countries of Asia and Africa, the rural population makes more than $2 / 3$ of overall population. In broad rural areas of European countries, there is about $40 \%$ of rural population, depending of the country. As opposed to the number of rural population which is constantly decreasing, the number of urban population is increasing more and more. Even when it was a dominant population in Europe, rural population didn't hold the structural power of political communities to which it belonged. The power was somewhere else. In fact, pesantry and the village are defined through their relationship with the surpreme Other.

Henri Mandras, the known French sociologist (represented in this collection) is very careful when studying rural pesant societies (Mendras, 1986). He is not prone to finding some general, alltimely and substantial definition of pesantry, because, as he says, there is no such „essential thing“, whose „eternal soul” has survived by penetrating „through a multitude of social changes”. He directs his research to clearly defined time and place: pesants of Western Europe between the year 1000 and 2000. By systematizing knowledge about them, he will build a model that could eventually help the research on other types of rural societies. When studying Europe, the Others in the eyes of pesants are firstly

\footnotetext{
1 alija@idi.hr
} 
noblemen and then the city. Mandras says: „when there is no nobleman or cities, there is no pesants". When urbanized and industrialized society annuls relative autonomy of pesant communities, the pesants are transformed into farmers, that is people who will become consumers, just like citizens -a peasant will stop baking his own bread, just like citizen does. From this observation, Mandras asks himself about the end of pesantry. Just as many binary divisions, the division city:village, urban:rural is historicaly determined. (Even the natural binary divisions that seem eternal and unchangable to us such are: man:woman, or day:night have been changed - imagine the change in our daily and nightly activities from the time of Rome, when the theft done by night was much severely punished than the one done in the daytime). This Mandras's binary division that determines pesantry will be used by the French historian (also represented in this collection), Emmanuel Le Roy Ladurie, to define the focus of his research interest - rural civilisation. According to him, the rural civilisation is defined firstly through opposites. Who says ,village“, by that he says "city“, who says „peasants“, at the same time says „citizens“. Rural civilization is a uniform tissue that gathers a certain number of cell groups: villages, parishes or communes. These groups, as the case may be, include, or are dominated by, some power, or (and) economic and social forces that are external or superior to those cells.Among such powers and forces that co-exist or follow one another, we can mention feudalism, cities, states, trade and industry, capitalism, party or police bureaucracy, etc. As Mandras notices - every village is surrounded by neighbouring society (other villages), and the dominating society (citizens, feudalists, capitalists, bureaucrats, clergy or police). (Le Roy Ladurie, in Vujović, 2016, p. 128)

They are all, exept (in part) feudalists, placed in the cities. When we ocasionally, or permanently, find them in a village - they represent the power which is located in the city. The binary division of the society into rural and urban is a long standing division, and is also one of the long-lasting social contradictions. It is no wonder it has its reflection in sociology, in the construction of concepts and in the description of studied phenomena, including those that have been built by city people since the medieval times - with some exeption conected to cultural and political ruralism. Thus, the owners of the ruling discourse, that is the city and its intellectuals use „the word peasant", in Declinatio rustica, from 13th century.Jacques Le Goff (1982) stresses in the introduction study of this collection and according to its editor, that this word „has six meanings: geak, unbeliever, robber, scoundrel, bandit, thief, and in plural: the miserables, beggers, thieves, liars, bullies, unbelievers, bastards“. Competence, courtesy, smoothness, moderation, rationality - they are all, according to the ruling discourse, placed in the city, not the village. In our concieusness we sometimes keep old prejudices, although they have no stronghold in the real life. Somewhat, it's the same with the binary divisions used in sociology- city:village, urban:rural, althoughit is (still) needed as a research tool, and a basic tool for organizing the complex, multifarious and changing reality. It is harmful, however, when it's blocking, or making difficult the recognition of true diversity and variabillity of studied phenomena.

The problem of rurality (and therefore urbanity) is the central problem of this collection, even when it's not mentioned. It exists in all the texts included in the study, directly and indirectly, as well as in the introductory study. And these texts are different in the way they analyse the mentioned issue and the time of writting: from the ones that 
analyse subject of sociology of rural development which rises the question of adequacy of the term that covers this topic in reality, through the texts which go to the far and near past and analyze changes made duringthe modernization of society, to the texts analyzing the present state of the village and rural population (its reproduction and culture). and the ones that anayze rural development in the context of post-socialist transformation of the village and rural population in modern Serbia.

The term "rurality“ is always explicitly or implicitly connetcted to the term „urbanity“ (since city is the bearer of change in modernity, and the place where changes happen, and that will sometimes touch the life and imagination of the village superficially, and sometimes totally), and it most often referes to the smaller settlements with low density of population and lack of buildings, the settlements with less developed division of work and withouth any central function. These are the settlements where agriculture is a significant activity (for some, basic, for some additional, and for some a recreational), and they are located in the landscape which is a wider area with fields, orchards, gardens, forests and sometimes water - a space that uses and valorizes its resources not only through agriculture but also, depending on the opportunities, through forestry, mining, electric power, water management, tourism, health, recreation, etc. These settlements are also connected tosimilar settlments and to some smaller town, creating alltogether one whole rural area. This is why we can't analyze these areas only or mainly through its agricultural activities, but through its integral development in which ecological aspect has important, and maybe even the most important place.

There are different patterns for mastering and arrangement of social complexity that is the result of modernization of the village, and is often connected to some research efforts. We will mention only one of them which can be used in number of disciplines - sociology, ahthropology and social geography. Bernard Kayser (1990) offered us an example of reserach the Western European villages, mostly in France. Within his recognition of the rural Renaissance process, he devides the process of transformation under the influence of modernization into two clearly recognizable periods.After the stage of composition, in which the rural community was in a state of coexistence of various occupations (agriculture, rural craftsmen, traders), there was the decomponing stage in a highly industrialized phase of modernization, in which village used agrarization to become monofunctional. After this, in modern conditions (thanks to modern development - with new forms of organization of work, development of road and other rural infrastructure, new means of communication, etc.) it became possible to live and work as the people of different occupations, and increased aspirations. This new emerging situation, Kayser calles - recomposition, and hence the Renaissance of rural areas.

It is good to analize rurality critically: from Portugal to the Rhodope Mountains in Bulgaria there is a mountain area, that without tourist, recreational, or some other productive function - are affected by depopulation, aging of the population and, accordingly, by reducing economic activity. In other parts of Europe, Renaissance usually affected rural areas near, or relatively near the urban settlements, where they tend to lose their resource, spatial and social density characteristics, as well as their landscape features. The same goes also for the settlments located near important road communications. It is, nevertheless, discovered that contemporary system of communication is the key for understanding this Renaissance. From the perspective of time-spatial compres- 
sion of David Harvey (1989), as a consequence of modern transport and telecommunication means and technologies, where spatial closeness is not an assumption of closeness among people, the new configuration of space also takes on new relations between the village and the city, and new definitions and classifications. For now, and according to the research results, the previous distinction still yields satisfactory results. There is no strict division between rural and urban. They are also interwined, but still - the distribution of structural features (economic, social, political and cultural) shows significant differences between them. Here, I am going to mention Karl Marx and Anatomy of Man, that helps to understand the anathomy of the apes i.e. the concept of urban:rural (where the urban generates and expands new values), with the notion of recomposing the rural (or some term similar to it) as devices for understanding the present, and at the same time can be used for better understanding of those processes and structures where rural population lived and reproduced. The division of the population into urban and rural is not only sustainable at world level, but also in a developed Western Europe where there are new practices of population recorded.

The texts published in this collection have different beginning points, and they alltogether encircle the whole range of problems that the sociology of village used to deal with and which are today the subject of sociology of rural development: from introductury study, to texts in the second part of the collection, summarized in six chapters - from basic texts in the field of this sociological discipline, to the texts which in contemporary Serbia recognize the problems of rural and regional development.

Today rural areas are again problematized. It is not just about exploiting their resources, but also about their protection, which becomes a new important development resource.Today, the production of space is reflection of modernity that is encompassing the current process of modernization and the growing problems of contemporary society. This means that the rural space should be perceived and valorized again. Organization of perception is provided by the insights into the previous development of rurality and its tranformation to already produced, along with the insights into the possible consequences of systematized knowledge about rurality, from different perspectives. To be able to produce rural space once again, and to organize new perception and valorization, we should begin from already existing knowledge and experiance. This collection, with its extensive introductory study and a very comprehensive selection of texts, offers a good starting point.

Sreten Vujović, the author of introductory study (Vujović, 2016, pp. 17-99) and the editor of this collection says that the collection "should primarily serve as a textbook for students at various levels of study, and in different colleges", but also can serve those who deal with social and humanistic studies, as well as the wider audience. It is possible to think of some other possible users of this collection: if the negligence is removed, which rules the government structure and the professional institutions in Serbia (important actors in the development of space), than this collection could be used for forming contemporary perception and valorization of rural space, in its planning and development - from municipal, to state level. 
Alija H. Hodžić, On rurality...

\section{REFERENCES / ЛИTEPATУPA}

Harvey, D. (1990). The Condition of Postmodernity: An Inquiry into the Origins of Cultural Change. Cambridge: MA \& Oxford UK: Blackwell.

Kayser, B. (1990). The Rural Renaissance. Paris: Armand Colin. [In French].

Le Goff, J. (1982). Intellectuals in the Middle Ages. Zagreb: Grafički zavod Hrvatske. [In Croatian].

Le Roy Ladurie, E.B. (2016). Rural Civilization. In U S. Vujović (ed.), Rural Development Sociology. Beograd: Zavod za udžbenike. [In Serbian].

Mendras, H. (1986). Peasant societies; elements for a theory of the peasantry. Zagreb: Globus. [In Croatian].

Vujović, S. (2016). Rural Development Sociology. Beograd: Zavod za udžbenike. [In Serbian]. 